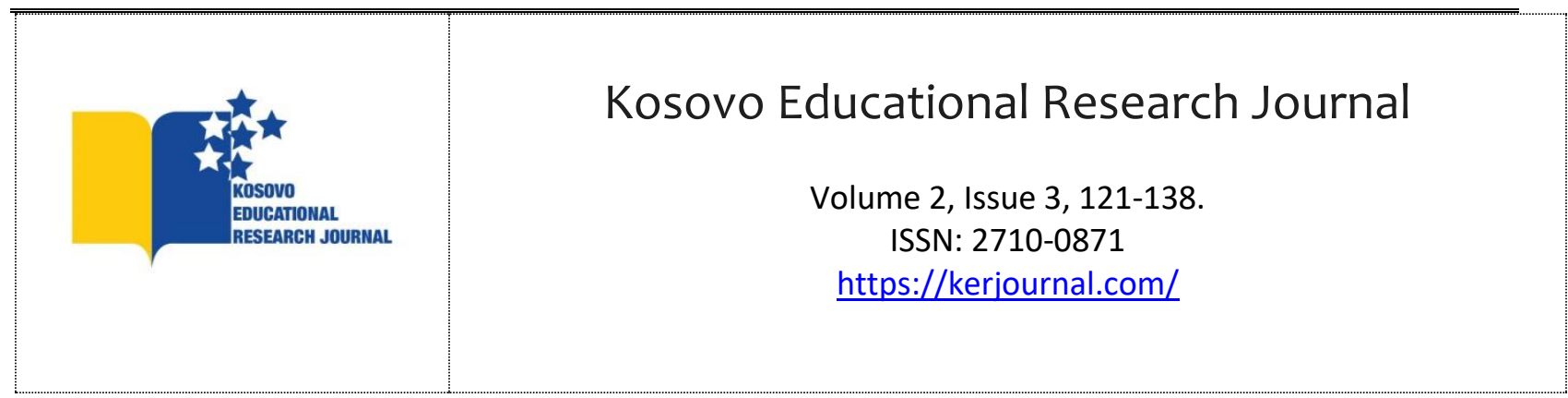

\title{
Kaynaştırma Öğrencilerin Sergilediği Problem Davranışlara Yönelik Sınıf Öğretmenlerinin Uyguladıkları Müdahale Stratejileri
}

\section{Mynever BASHA}

Prizren Ukshin Hoti Üniversitesi

\begin{abstract}
ÖZET: Her bireyin öğrenme biçimi, hızı ve öğrendiklerini uygulaması farklılıklar gösterebilmektedir. Her birey diğer akranlarıyla aynı kapasitede olmayabilir ve farklılık gösterebilir. Günümüzde özel gereksinimli birey sayısı giderek artmakta. Bu artışın sebebi çevresel nedenler, erken doğum veya tıbbın ileri derecede sağlık sorununa sahip olan bebekleri yaşatmaları, trafik kazaları, annenin bebeğiyle kan uyuşmazlığı, annenin yaşı 17 'den küçük 35'ten büyük olması, annenin kronik hastalıkları, annenin madde bağımlısı (alkool, sigara, uyuşturucu) olması, doğum sonrası bebeğin farklı hastalıkları ve daha fazla nedenlere dayanabilmektedir. Sınıf öğretmeni, özel öğrenciyi en iyi şekilde yetiştirmelidir: aynı yaştaki akranlarıyla aynı ortamda eğitilmeli, onların sosyaleşmelerine yardımcı olmalıdır, özel öğrencinin yeteneklerini keşfedip onları geliştirmelidir. Böylece özel gereksinimli öğrenciler, öğretmenleri ve aileleri yardımıyla kendilerini özgürleştirebilirler ve bağımsız yaşam becerilerini kazanarak mutlu ve aktif birer birey olabilirler. Özel gereksinimli öğrencilerin önemini dikkate alarak Kaynaştırma Öğrencilerin Sergilediği Problem Davranışlara Yönelik Sınıf Öğretmenlerinin Uyguladıkları Önleme ve Müdahale Stratejileri ve Yöntemleri adı altında çalışma yapılması uygun görülmüştür.Sınıf öğretmeni, özel gereksinimli olan öğrencilerin eğitilmesi normal gelişim gösteren çocukların bulunduğu sınıfta kaynaştırılmasında güclü bir arabulucudur. Bu araştırmanın genel amacını, 2020/2021 eğitim-öğretim yılı Prizren, Mamuşa ve Priştine illerinde bulunan ilkokullarda görev yapan Sınıf Öğretmenlerinin bazı demografik özelliklere göre kaynaştırmada öğretmen yeterliklerinin belirlenmesi ve öğretmen yeterlikleri arasındaki ilişkinin incelenmesi oluşturmaktadır. Bu araştırma nicel araştırma yönteminde tasarlanmıştır. Araştırmaya 46 öğretmen katılmıştır. Öğretmenlerin çoğu velilerin özel çocukların eğitilmesinde büyük katkı sağladıkları savunmuştur. Ayrıca öğretmenlerin görüşlerinden bir diğeri de özel çocukların eğitilmesinde okulun araçgereçlerinin günümüze uygun bir düzeyde var olmasını savunmuşlardır.
\end{abstract}

Anahtar Kelimeler: Özel gereksinimli birey, Sınıf Öğretmeni, Kaynaştırma 
To cite this article: Basha, M. (2021). Kaynaştırma Öğrencilerin Sergilediği Problem Davranışlara Yönelik Sınıf Öğretmenlerinin Uyguladıkları Müdahale Stratejileri. Kosovo Educational Research Journal, 2(3). 121-138.

\section{GíRIŞ}

Her bireyin öğrenme biçimi, hızı ve öğrendiklerini uygulaması farklılıklar gösterebilmektedir. Her birey diğer akranlarıyla aynı kapasitede olmayabilir ve farklılık gösterebilir. Bazı bireyler doğuştan beri bazıları da doğumdan sonra farklılık gösterebilirler. Öğrenmeye ilişkin bireysel farklılıklar bazen belli bir nedene bağlı olabilir, bazen de herhangi bir nedene bağlı olmayabilmektedir.

Milli Eğitim Bakanlığı Özel Eğitim Hizmetleri Yönetmenliğinde tanımladığı şekilde: “özel eğitim gerektiren birey, çeşitli nedenlerle bireysel özellikleri ve eğitim yeterlilikleri açısından akranlarına göre beklenilen düzeyden anlamlı farklılık gösteren bireyi " ifade etmektir. Özel gereksinimli olan çocukların farklılıkları zihinsel, duygusal, bedensel, duygusal ve sosyal ya da iletişim özelliklerinde ya da bunların herhangi bir bileşeninde olabilir (Eripek, 2005: s. 5, Aktaran: ŞAHBAZ, Ü., \& KALAY, G. 2010). Özel gereksinimli bireylerin toplumsal görevlerini yerine getirmeleri için bağımsız bir yaşam sürdürmeleri çok önemlidir. Bu bağımsızlığın kazandırılması için bireylerin ihtiyaç ve becerilerine göre eğitim programı belirlenip bu ihtiyaçlar uygun eğitim ortamlarında sunulmalıdır.

Kaynaştırma da bu bireysel farklılıklara göz önüne alındığında ve bazı öğrencilerin sahip oldukları engel türüne, içinde yaşadıkları çevresel ve biyolojik risk koşullarına ya da öğrenme daha ileri performanslarına (üstün zeka/yetenek) bağlı olarak normal gelişim gösteren aynı yaştaki akranlarıyla birlikte normal şartlar altında (eğitim müfredatı, sınıf, koşullar) eğitim görmelerini sağlar.

Sınıf öğretmeni, özel gereksinimli olan öğrencilerin eğitilmesi normal gelişim gösteren çocukların bulunduğu sınıfa kaynaştırılmasında güclü bir arabulucudur.

\section{YÖNTEM}




\section{Araștırma Modeli}

Belirlenen bir evren içerisinden seçilen örneklem ile çalışarak, ulaşılan sonuçlarla evren hakkında genel bir yargıya varılabilen araştırma modeli 'genel tarama modeli' olarak tanımlanmaktadır. Genel tarama araştırmaları tekil ya da ilişkisel olarak yapılabilmektedir (Karasar, 2005).

$\mathrm{Bu}$ araştırmada Kaynaştırma Öğrencilerin Sergilediği Problem Davranışlara Yönelik Sınıf Öğretmenlerinin Uyguladıkları Önleme ve Müdahale Stratejileri ve Yöntemleri’ni incelemek amacıyla tarama çalışması olarak tasarlanmıştır.

$\mathrm{Bu}$ araştırma nicel araştırma yönteminde tasarlanmıştır. Nicel araştırma yaşanan olguları ve olayları nesnelleştirerek gözlemlenebilir duruma getiren araştırmalardır. Nicel araştırma sayısal araştırma olarak da bilinmektedir.

\section{Evren ve Örneklem}

Evren; araştırma sonuçlarının genellenmek istendiği elemanlar bütünüdür (Karasar,2010). Araştırmanın evreni; Kosova'da Türkçe Eğitim veren ilkokullarda, bu okullarda çalışan Sınıf Öğretmenlerin den oluşmaktadır.

Örneklem; belirli bir evrenden, belirli kurallara göre seçilmiş ve seçildiği evreni temsil yeterliliği kabul edilen küçük kümedir (Karasar,2010). Araştırmanın örneklemi belirlenirken amaçsal örnekleme ile araştırmanın yapılacağı okullar seçilmiş ve bu okullardan Türkçe eğitim veren, Prizren, Priştina ve Mamuşa Beledediyesindeki okullarındaki sınıf öğretmenlerine uygulanmıştır.

Araştırma Prizren Belediyesinde 5 devlet ilkokulunda (Abdyl Frashëri, Mati Logoreci, Motrat Qiriazi, Mustafa Baki, Emin Duraku), Mamuşa Belediyesindeki “Anadolu” İlkokulunda ve Priştine Belediyesindeki “Elena Gjika” İlkokulunda 46 Öğretmen ile görüşme yapılmıştır.

\section{Tablo 3.2.1. Araştırmaya katılan öğretmenlerin cinsiyet dağılımı}

\begin{tabular}{rr|r|r} 
& Frekans & \multicolumn{1}{l|}{ Yüzdle } & \multicolumn{1}{l}{ Toplam } \\
& & & \\
\hline Kadın & 39 & $84.8 \%$ & $84.8 \%$ \\
\hline Erkek & 7 & $15.2 \%$ & $100.0 \%$ \\
\hline
\end{tabular}




\begin{tabular}{ll|l|l}
\hline Total & 46 & $100.0 \%$ & $100.0 \%$ \\
\hline
\end{tabular}

Yukarıda 3.2.1. tabloda'ki görüldüğü gibi 46 öğretmenlerin 39 katılımcıların kadın, 7 katılımcıların ise erkek oluşturduğu görülmektedir.

\section{Bulgular}

$\mathrm{Bu}$ bölümde, araştırmada ele alınan amaçlar doğrultusunda elde edilen verilerin istatistiksel analizleri sonucunda elde edilen bulgularına yer verilmiştir. Bulgular, amaçların diziliş sırası dikkate alınarak sunulmuştur.

\section{Araştırmaya katılan öğretmenlerin yaş dağılımı}

Öğretmenlerin yaş dağılımları bakıldığında araştırmaya katılan 46 öğretmenlerden: 22-30 yaş arası öğretmenelerin sayısı 1 (2.2\%), 30-40, 40-50 ve 50-65 yaşlar arasındaki öğretmenelerin sayısı 15 $(32.6 \%)$ oluşturmakta. Bu veriler aşağıdaki tablo 1 'de sunulmuştur.

\section{Tablo 1. Araştırmaya katılan öğretmenlerin yaş dağılımı}

\begin{tabular}{|c|c|c|}
\hline \multicolumn{2}{|c|}{ Frekans } & Yüzde \\
\hline $22-30$ & 1 & $2.2 \%$ \\
\hline $30-40$ & 15 & $32.6 \%$ \\
\hline $40-50$ & 15 & $32.6 \%$ \\
\hline $50-65$ & 15 & $32.6 \%$ \\
\hline Total & 46 & $100.0 \%$ \\
\hline
\end{tabular}

\section{Öğretmenlerin belirlenen sorulara verdikleri cevapları}

Araştırmada öğretmenlere yöneltilen sorulara ve sonuçlar aşağıdaki tablo 2'de sunulmuştur. 


\section{Kosovo Educational Research Jorunal}

Tablo 2. Öğretmenlerin belirlenen sorulara verdikleri cevapları

\begin{tabular}{|c|c|c|c|c|c|c|c|c|}
\hline & \multicolumn{2}{|c|}{$\begin{array}{c}\text { Kariyeriniz boyunca } \\
\text { özel eğitime muhtaç } \\
\text { oğrencilere } \\
\text { rastladınız mı? }\end{array}$} & \multicolumn{2}{|c|}{$\begin{array}{c}\text { Diğer öğrencilerimle } \\
\text { ilgilenirken } \\
\text { kaynaştırma } \\
\text { öğrencisine } \\
\text { yeterince zaman } \\
\text { ayırmakta } \\
\text { zorlanırım. }\end{array}$} & \multicolumn{2}{|c|}{$\begin{array}{l}\text { Normal gelişim } \\
\text { gösteren öğrenciler } \\
\text { derslerde veya } \\
\text { etkinlikler sırasında } \\
\text { kaynaştırma } \\
\text { öğrencileriyle aynı } \\
\text { sırada veya grupta } \\
\text { olmak } \\
\text { istememektedir. }\end{array}$} & \multicolumn{2}{|c|}{$\begin{array}{c}\text { Kaynaştırma } \\
\text { öğrencisi sınıf içinde } \\
\text { birçok etkinliğe } \\
\text { katılamadığından } \\
\text { eğitimin dışında } \\
\text { kalmaktadır }\end{array}$} \\
\hline Valid & & 46 & & 46 & & 46 & & 46 \\
\hline Missing & & 0 & & 0 & & 0 & & 0 \\
\hline Mean & \multicolumn{2}{|c|}{1.2391} & & 1.9783 & & 2.1087 & & 1.8696 \\
\hline Std. Deviation & \multicolumn{2}{|c|}{.43127} & \multicolumn{2}{|r|}{.77428} & \multicolumn{2}{|r|}{.76676} & \multicolumn{2}{|r|}{.77771} \\
\hline & $\begin{array}{c}\text { Kaynaştırma } \\
\text { öğrencisiyle } \\
\text { iletişim kurarken } \\
\text { iç dünyasını } \\
\text { anlamakta ve } \\
\text { tepkilerini } \\
\text { kestirmekte } \\
\text { zorlanırım. }\end{array}$ & \multicolumn{2}{|c|}{$\begin{array}{c}\text { Kaynaştırma } \\
\text { öğrencileri } \\
\text { normal gelişim } \\
\text { gösteren } \\
\text { öğrencilere } \\
\text { fiziksel olarak } \\
\text { zarar } \\
\text { verebilmektedir }\end{array}$} & \multicolumn{2}{|c|}{$\begin{array}{c}\text { Kaynaştırma } \\
\text { öğrencisi ders } \\
\text { sırasında normal } \\
\text { gelişim gösteren } \\
\text { öğrencilerin } \\
\text { dikkatini } \\
\text { dağıtmaktadır. }\end{array}$} & \multicolumn{2}{|c|}{$\begin{array}{c}\text { Veliler } \\
\text { kaynaştırma } \\
\text { öğrencisinin } \\
\text { durumunu } \\
\text { kabullenmekte } \\
\text { güçlük } \\
\text { çekmektedirler }\end{array}$} & $\begin{array}{l}\text { Kaynaştırma } \\
\text { uygulaması } \\
\text { sırasında } \\
\text { kaynaştırma } \\
\text { öğrencilerinin } \\
\text { velileri diğer } \\
\text { öğrencilerin } \\
\text { velileriyle } \\
\text { sorunlar } \\
\text { yaşamaktadır }\end{array}$ \\
\hline Valid & 46 & & 46 & & 46 & & 46 & 46 \\
\hline Missing & 0 & & 0 & & 0 & & 0 & 0 \\
\hline Mean & 1.9565 & & 2.1957 & & 1.9783 & 1.8 & 478 & 2.0652 \\
\hline Std. Deviation & .63093 & & .74891 & & 90650 & .86 & 839 & .71187 \\
\hline
\end{tabular}




\section{Kosovo Educational Research Jorunal}

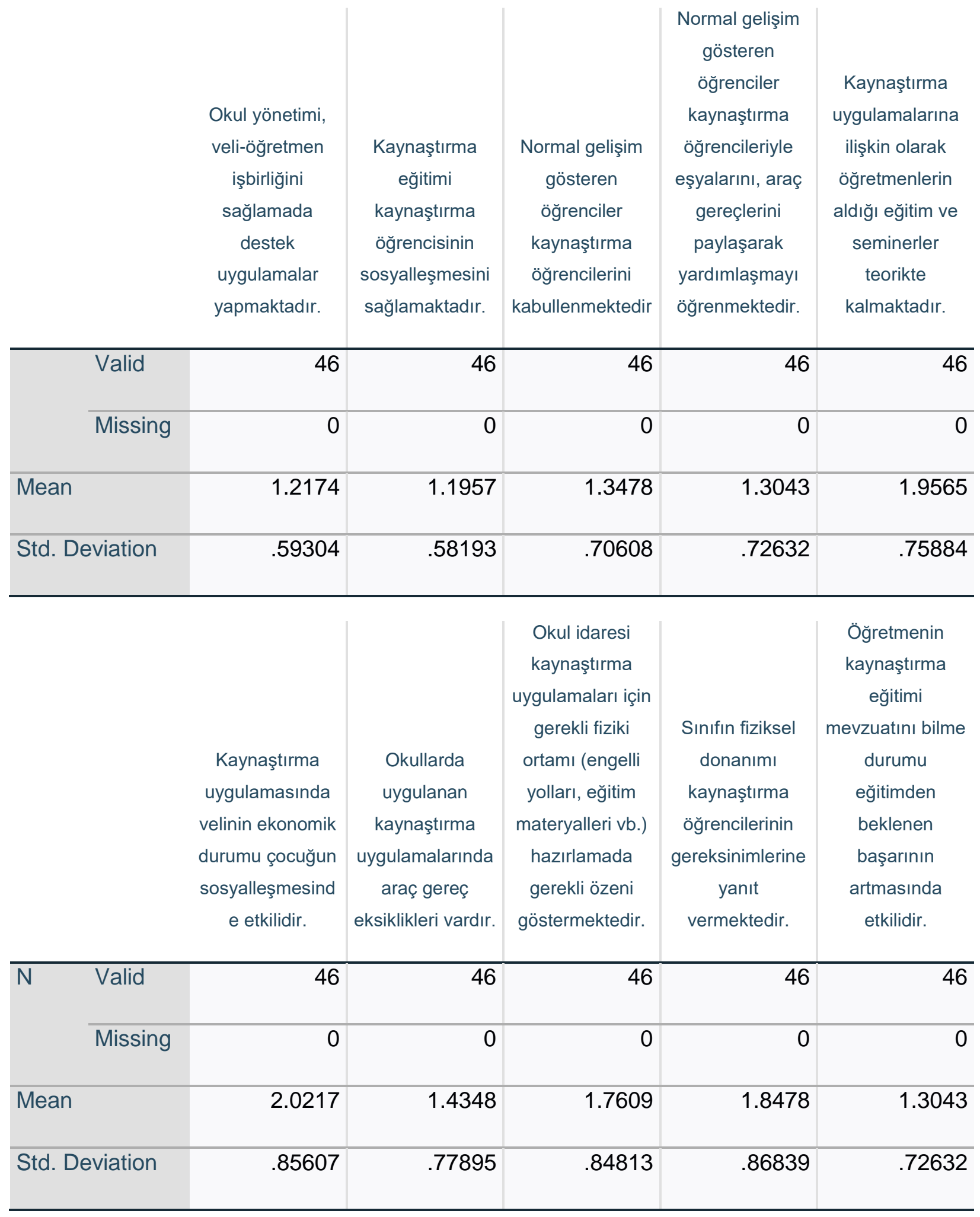




\section{Araştırmaya katılan öğretmenlerin ders verdikleri sınıf dağılımları}

Araştırmada birinci sınıfa ders verdikleri öğretmenlerin sayısı 8 (17.4\%), ikinci, üçüncü ve dördüncü sınıflara ders verdikleri öğretmenlerin sayısı 9 (19.6\%) ve beşinci sınıfların öğretmenlerin sayısı 11 (23.9\%) oluşmaktadır. Bu veriler aşağıdaki tablo 3’te sunulmuştur.

Tablo 3. Araştırmaya katılan öğretmenlerin ders verdikleri sınıf dağılımları

\begin{tabular}{rr|r|} 
& Frekans & Yüzde \\
\hline 1.Sınıf & 8 & $17.4 \%$ \\
\hline 2.Sınıf & 9 & $19.6 \%$ \\
\hline 3.Sınıf & 9 & $19.6 \%$ \\
\hline 4.Sınıf & 9 & $19.6 \%$ \\
\hline 5.Sınıf & 11 & $23.9 \%$ \\
\hline Total & 46 & $100.0 \%$ \\
\hline
\end{tabular}

4.4. Öğretmenlerin Kariyerleri boyunca özel eğitime muhtaç öğrencilere rastlama incelenmesi

Analize göre, araştırmaya katılan 46 Sınıf Öğretmenlerinden on biri (23.9\%) kariyerleri boyunca hiç özel eğitime muhtaç öğrenciye rastlamamış. Bu veriler aşağıdaki tablo 4 'te sunulmuştur.

Tablo 4. Öğretmenlerin Kariyerleri boyunca özel eğitime muhtaç öğrencilere rastlama incelenmesi

\begin{tabular}{lr|r|} 
& Frekans & \multicolumn{1}{l}{ Yüzde } \\
\hline Evet & 35 & $76.1 \%$ \\
\hline Hayır & 11 & $23.9 \%$ \\
\hline
\end{tabular}




\begin{tabular}{l|l|l|}
\hline Total & 46 & $100.0 \%$ \\
& & \\
\hline
\end{tabular}

Öğretmenlere göre etkinlik sırasında normal gösteren öğrenciler kaynaştırma öğrencileriyle aynı sırada veya grupta olmak isteme güdülerin incelenmesi

Tablo 5. Öğretmenlere göre etkinlik sırasında normal gösteren öğrenciler kaynaştırma öğrencileriyle aynı sırada veya grupta olmak isteme güdülerin incelenmesi

Normal gelişim gösteren öğrenciler derslerde veya etkinlikler sırasında kaynaştırma öğrencileriyle aynı sırada veya grupta olma isteklerin olup olmadığını asağıdaki tabloda sunulmuştur.

\begin{tabular}{ll|r|r|} 
& & Frequency & Percent \\
\hline Valid & Evet & 11 & $23.9 \%$ \\
\cline { 3 - 3 } & Hayır & 19 & $41.3 \%$ \\
& & \\
\hline Kararsızım & 16 & $34.8 \%$ \\
\hline Total & 46 & $100.0 \%$ \\
\hline
\end{tabular}

Tablo 5'te görüldüğü üzere \%41.3'ü etkinlikler sırasında veya derslerde kaynaştırma öğrencileri ile aynı sırada oturmakta sıkıntı çekmiyorlar.

\section{Araştırmaya katılan öğretmenlerin diğer öğrencileriyle ilgilenirken kaynaştırma öğrencisine yeterince zaman ayırmakta zorluk çektiklerinin incelenmesi}

Gün boyunca normal sınıfta, ders sırasında aynı anda hem kaynaştırma öğrencileriyle hem de normal öğrenciler ile yeterince zaman ayırıp ayırmadıklarının incelenmesi asağıdakı tablo 6'da gösterilmiştir.

Tablo 6. Araştırmaya katılan öğretmenlerin diğer öğrencileriyle ilgilenirken kaynaştırma öğrencisine yeterince zaman ayırmakta zorluk çektiklerinin incelenmesi 
Aşağıdaki tablo 6'da gösterildiği gibi öğretmenlerin: Diğer öğrencilerimle ilgilenirken kaynaştırma öğrencisine yeterince zaman ayırmakta zorlanırım sorusuna 46 öğretmenlerden ondördü evet cevabını, ondokuzu hayır ve onüç öğretmenler kararsızım cevabını vermiştirler.

\begin{tabular}{l|r|r|} 
& Frekans & \multicolumn{1}{l}{ Yüzde } \\
\hline Evet & 14 & $30.4 \%$ \\
\hline Hayır & 19 & $41.3 \%$ \\
\hline Kararsızım & 13 & $28.3 \%$ \\
\hline Total & 46 & $100.0 \%$ \\
\hline
\end{tabular}

4.7. Öğretmenlerin Kaynaştırma Öğrencileri ile iletişim kurarken iç dünyalarını anlamakta zorlanmaları

Aşağıdaki tablo 7'de görüldüğü gibi öğretmenlerin Kaynaştırma Öğrencileri ile iletişim kurarken iç dünyalarını anlamakta zorlanmaları hakkında katılımcıların onu evet cevabını vermiştirler, yirmisekizi hayır ve sekizi kararsızım cevaplarını savunmaktadır.

\section{Tablo 7. Öğretmenlerin Kaynaştırma Öğrencileri ile iletişsim kurarken iç dünyalarını anlamakta} zorlanmaları

\begin{tabular}{lr|r|} 
& Frekans & \multicolumn{1}{l}{ Yüzde } \\
\hline Evet & 10 & $21.7 \%$ \\
\hline Hayır & 28 & $60.9 \%$ \\
\hline Kararsızım & 8 & $17.4 \%$ \\
\hline Total & 46 & $100.0 \%$ \\
\hline
\end{tabular}




\section{Öğretmenlerin kaynaştırma öğrencilerin ders sırasında normal gelișim gösteren öğrenciler ile dikkatlerin dağılmaların karşılaştırılması}

Öğretmenlerin \%41.3 kaynaştırma öğrencileri ders sırasında normal gelişim gösteren öğrencilerin dikkatlerini dağıtıklarını düşüncelerinde, \%19.6 kaynaştırma öğrencilerin normal öğrencilere dikkatlerini dağıtmadıklarını savunmaktadır, \%39.1 bu konuda kararsız olduklarını düşüncelerindedir. $\mathrm{Bu}$ veriler aşağıdaki tablo 8 'de sunulmuş̧ur.

Tablo 8. Öğretmenlerin kaynaştırma öğrencilerin ders sırasında normal gelişim gösteren öğrenciler ile dikkatlerin dağılmaların karşılaştırılması

\begin{tabular}{lr|r|} 
& Frekans & Yüzde \\
\hline Evet & 19 & $41.3 \%$ \\
\hline Hayır & 9 & $19.6 \%$ \\
\hline Kararsızım & 18 & $39.1 \%$ \\
\hline Total & 46 & $100.0 \%$ \\
\hline
\end{tabular}

Araştırmaya katılan öğretmenlere göre velilerin kaynaştırma öğrencilerin kabullenmekte güçlük çektikleri düşünceleri

Aşağıdaki tablo 9'da sunulduğu gibi öğretmenlerin 21'i velilerin kaynaştırma öğrencisinin durumunu kabullenmekte güçlük çektiklerinin düşüncesindedir, 11'i buna katılmadıklarını ve 14'ü kararsız olduklarını belirlemiştirler.

Tablo 9. Araştırmaya katılan öğretmenlere göre velilerin kaynaştırma öğrencilerin kabullenmekte güçlük çektikleri düşünceleri

\begin{tabular}{cr|r} 
& Frekans & Yüzde \\
\hline Evet & 21 & $45.7 \%$ \\
\hline
\end{tabular}




\begin{tabular}{l|r|r|}
\hline Hayır & 11 & $23.9 \%$ \\
\hline Kararsızım & 14 & $30.4 \%$ \\
\hline Total & 46 & $100.0 \%$ \\
\hline
\end{tabular}

Öğretmenlerin okul yönetimi, veli-öğretmen işbirliğini sağlamada destek uygulamar yapıldığının düşünceleri

Sorulan soruda öğretmenlerin okul yönetimi ve veli-öğretmen işbirliğini sağlamada destek uygulamar yapıldığının düşüncelerinin aşağıdaki tablo 10’da sunulmuştur.

\section{Tablo 10. Öğretmenlerin okul yönetimi, veli-öğretmen işbirliğini sağlamada destek uygulamar} yapıldığının düşünceleri

Öğretmenlerin \%87 (40 kişi) okul yönetimi ve veli-öğretmen işbirliğini sağlamada destek uygulamar yapıldığını düşüncesindedirler, \%4.3 (2 kişi) bu düşünceye katılmadıklarını ve \%8.7 (4 kişi) bu durumda kararsız olduklarını belirtmişlerdir.

\begin{tabular}{lr|r|} 
& Frekans & \multicolumn{1}{c|}{ Yüzde } \\
\hline Evet & 40 & $87.0 \%$ \\
\hline Hayır & 2 & $4.3 \%$ \\
\hline Kararsızım & 4 & $8.7 \%$ \\
\hline Total & 46 & $100.0 \%$ \\
\hline
\end{tabular}

\section{Kaynaştırma eğitimi kaynaştırma öğrencisinin sosyalleşmesini sağlamaktadır}

Araştırmaya katılan öğretmenlerin 41 kaynaştırma eğitimi kaynaştırma öğrencisinin sosyalleşmesini sağladığını savunmaktadır, 1 kişi bu düşünceyi savunmadığını belirtmiştir ve 4 kişi karasız olduklarını belirtmiştir. Bu veliler aşağıdakı Tablo 11 sunulmuştur. 
Tablo 11. Kaynaştırma eğitimi kaynaştırma öğrencisinin sosyalleșmesini sağlamaktadır.

\begin{tabular}{ll|r|r} 
& \multicolumn{2}{c|}{ Frekans } & \multicolumn{1}{c}{ Yüzde } \\
\hline Valid & Evet & 41 & $89.1 \%$ \\
\cline { 2 - 3 } & Hayır & 1 & $2.2 \%$ \\
\cline { 2 - 2 } & & \\
\hline Kararsızım & 4 & $8.7 \%$ \\
\hline Total & 46 & $100.0 \%$ \\
\hline
\end{tabular}

Öğretmenlere göre normal gelişim gösteren öğrenciler kaynaştırma öğrencileriyle eşyalarını, araç gereçlerini paylaşarak yardımlaşmayı öğrenmektedir.

Katılımcıların 39’u (\%84.9) normal gelişim gösteren öğrenciler kaynaştırma öğrencileriyle eşyalarını paylaşarak yardımlaşmayı öğrendiklerini düşüncesindedirler, 7 kişi (\%15.2) kararsız olduklarını belirtmiştir. Bu veliler Tablo 12'de sunulmuştur

Tablo 12. Öğretmenlere göre normal gelişim gösteren öğrenciler kaynaştırma öğrencileriyle eşyalarını, araç gereçlerini paylaşarak yardımlaşmayı öğrenmektedir.

\begin{tabular}{l|r|r|} 
& & \\
& & \\
& Frekans & \multicolumn{1}{c|}{ Yüzde } \\
\hline Evet & 39 & $84.8 \%$ \\
\hline Kararsızım & 7 & $15.2 \%$ \\
\hline Total & 46 & 100.05 \\
\hline
\end{tabular}

Öğretmenlere göre okullarda uygulanan kaynaştırma uygulamalarında araç gereç eksiklikleri vardır 
Tablo 13'te sunulduğu gibi öğretmenlerin \%73.9 (34 kişi), okullarda uygulanan kaynaştırma uygulamalarında araç gereç eksiklikleri olduğu düşüncelerindedir, \%8.7 (4 kişi) bu soruya katılmadıklarını ve öğretmenlerin \%17.4 (8 kişi) bu durumda karasız olduklarını belirtmişlerdir.

Tablo 13. Öğretmenlere göre okullarda uygulanan kaynaştırma uygulamalarında araç gereç eksiklikleri vardır

\begin{tabular}{|c|c|c|}
\hline & & Yüzde \\
\hline Evet & 34 & $73.9 \%$ \\
\hline Hayır & 4 & $8.7 \%$ \\
\hline Kararsızım & 8 & $17.4 \%$ \\
\hline Total & 46 & $100.0 \%$ \\
\hline
\end{tabular}

\section{Kaynaştırma uygulamasında velinin ilgisi çocuğun sosyalleşmesini etkilemektemidir incelenmesi}

Aşağıdaki Tablo 14 te görüldüğü gibi öğretmenlerin \%84.8 (39 kişi) kaynaştırma uygulamasında velinin ilgisi çocuğun sosyalleşmesini etkilemektedir düşüncesindedirler, \%4.3 (2 kişi) buna katılmamaktadırlar ve \%10.9 (5 kişi) kaynaştırma uygulamasında velinin ilgisi çocuğun sosyalleşmesini etkiler mi kararsız kalmışlardır.

Tablo 14. Kaynaştırma uygulamasında velinin ilgisi çocuğun sosyalleşmesini etkilemektemidir incelenmesi

\begin{tabular}{|c|c|c|}
\hline & & Yüzde \\
\hline Evet & 39 & $84.8 \%$ \\
\hline Hayır & 2 & $4.3 \%$ \\
\hline Kararsızım & 5 & $10.9 \%$ \\
\hline Total & 46 & $100.0 \%$ \\
\hline
\end{tabular}




\section{Sonuç ve Öneriler}

Özel gereksinimli çocukların sayısı gün geçtikte daha da fazla artmakta. Özel bir çocuğu en güzel şekilde yetiştirmek için en önemli kişiler ilk sırada anne-baba ve aile sonra da öğretmendir.

Tıpkı el parmaklarımızın aynı olmadığı gibi her çocuk’ta aynı değildir. Bazı çocuklar özel doğarlar. Ailede veya okulda farklı problemler sergileyebilirler ama önemli olan ebeveyinlerin bu duruma hakim olması.

Bir bireyin kendine yapacağı en temel şeylerden bir tanesi kendini sevmesidir. Maalesef çeşitli önyargılardan dolayı eskiden (hatta günümüzde) özel çocuklar bu duyguyu belkide hiç tatmamışdırlar. Anne babalar ve aileler bu duruma ilk önce kabullenip sonrada çözümlere odaklanmalıdırlar.

Aileden sonra özel çocukların kendilerini sevme, sosyalleşmelerine, yeteneklerini keşfetmeleri, diğer akranlarıyla aynı ortamda eğitilmelerin görevi öğretmenlere düşer. Bu yüzden öğretmenin özel eğitim ve kaynaştırma hakkında bilgili olmalıdır.

Araştırmamızda öğretmenlerin bilgi ve tutumlarını ele alarak: özel çocukların sergilediği problemlere karşı öğretmenlerin uyguladıkları önleme ve müdahalelerini inceledik. Araştırma Prizren, Mamuşa ve Priştina illerinde sınıf öğretmenleriyle yapılmıştır. Bu araştırmada toplam 46 öğretmen katılmıştır (39 kadın, 7 erkek).

$\mathrm{Bu}$ konu hakkında öğretmenlerimize "Kariyerleri boyunca özel eğitime muhtaç öğrencilere rastladınız mı?" sorusuna \%76.1 rastladıkarını belilemiştirler diğer \%23.9 öğretmenler grubu ise hiç rastlamadıklarını vurgulamıştırlar. Bu büyük yüzdenin sebebi günümüzde çok sayıda özel çocukların doğdundan olabilir ve aynı zamanda özel öğrenciler normal öğrenciler ile aynı ortamda eğitildikleri için artık hemen hemen her sınıfta özel gereksinimli çocuklar bulunmaktadır. Hayır diyen kısım ise genç yaşlarda oldukları için ve uzun kariyer oluşturmadıkları için sınıflarında özel öğrencilere hiç rastlamamış olabilirler.

Öğretmenlerimize sorduğumuz soruda "Normal gelişim gösteren öğrenciler derslerde veya etkinlikler sırasında kaynaştırma öğrencileriyle aynı sırada veya grupta olmak istememektedirler" 
\%23.9'u evet, \%41,3 hayır, \%34.8'i kararsızım cevaplarını vermiştirler. Normal gelişim gösteren öğrenciler küçük yaşlardan itibaren biraz daha fazla bilgili olabiliyorlar çünkü artık internet sayesinde daha verimli olabiliyorlar ve aynı zamanda günümüzde anne çocuk iletişimi daha güçlenmiştir.

Ankette sorduğumuz soruda: "Diğer öğrencilerimle ilgilenirken kaynaştırma öğrencisine yeterince zaman ayırmakta zorlanırım" öğretmenlerin \%30.4'u evet cevabını vermiştirler, \%41.3'ü buna katılmadıklarını ve \%28.3'ü kararsız olduklarını belirtmişlerdir. Bunun sebebi öğretmenlerin farklı seminerlere katılarak derse olan hakimlikleri daha fazla olmaları ve çeşitli etkinlikler uygulayarak bütün öğrencilerin dikkatlerini çekebilmektedirler.

Öğretmenlerimize sorduğumuz soruda: "Kaynaştırma öğrencisiyle iletişim kurarken iç dünyasını anlamakta ve tepkilerini kestirmekte zorlanırım" öğretmenlerin \%21.7'i evet cevabını, \%60.9'u hayır ve \%17.4'ü kararsız olduklarını belirtmişlerdir. \%50'den fazlası kaynaştırma öğrencisiyle iletişim kurarken iç dünyasını anlamkta zorlanmadıklarının sebebi artık özel çocuklar hakkında internette, kitaplarda, gazetelerde, dergilerde çok fazla bilgiler edinebilirler. Aynı zamanda öğretmenleri iş tecrübeleri özel çocukları anlamakta çok önemlidir.

Sorulan soruda: "Kaynaştırma öğrencisi ders sırasında normal gelişim gösteren öğrencilerin dikkatini dağıtmaktadır” öğretmenlerin \%41.3'ü evet cevabını, \%19.6 hayır ve \%39.1'i kararsızım cevabını vermiştirler. Çoğu öğretmenlerin evet cevabını vermelerinin sebebi özel öğrencinin daha fazla ilgilenmeleri gerektiğini ama zamanın kısa olması, sınıftaki öğrencilerin sayısı fazla olması, sınıfta her zaman gerekli olan araç-gereçlerin bulunmaması öel öğrencinin sıkılmasına neden olabilir ve bu yüzden özel öğrenci farklı jestler yapabilir ve diğer öğrencilerin dikkatlerini kolayca dağıtabilir. Öğretmenlerle yaptı̆̆ımız görüşlerde normal öğrencilerin yaşları küçükken dikkatleri daha çabuk dağılabilir ve özellikle 1 ve 2 'nci sınıflarda özel öğrenci ile alışmaları daha zor geçebiliyor. Normal öğrenciler büyüdükçe, özel öğrencilerle alışıyorlar ve dikkatleri daha zor dağılabiliyor.

Sorulan soruda: "Veliler kaynaştırma öğrencisinin durumunu kabullenmekte güçlük çekmektedirler" öğretmenlerin \%45.7'i evet, \%23.9'u hayır ve \%30.4'ü kararsızım cevabını vermiştirler. Günümüzde'de hala ebeveyinler çocuklarının özel gerekssinimli olduklarını 
kabullenmiyorlar. Bunun sebebi diğer kişilerin önyargıları veya okulda çocuklarının dışlanması korkusu olabilir.

Anketimizde 10'uncu soruda: “Okul yönetimi, veli-öğretmen işbirliğini sağlamada destek uygulamalar yapmaktadır” öğretmenlerin \% 87.0'si katıldıklarını, \%4.3'ü buna katılmadıklarını ve \%8.7'si kararsız olduklarını belirtmişlerdir. Soruya \%87'si evet cevabını vermelerinin sebebi özel öğrenci sadece öğretmen tarafından en iyi şekilde yetiştirilemez. Özel öğrencinin okulda geçirdikleri zaman bellidir ve bu kısıtlı zamanda öğrencinin bütün gereksinimleri karşılanamaz. Bu yüzden okul yönetimi veli-öğretmen işbirliği özel öğrencinin kendini geliştirmesinde çok önemlidir.

Öğretmenlerimize sorduğumuz soruda: "Kaynaştırma eğitimi kaynaştırma öğrencisinin sosyalleşmesini sağlamaktadır” \% 89.1'i buna katıldıklarını vugulamıştırlar. Özel öğrenci kendi yaşındaki arkadaşlarıyla, aynı ortamda eğitim aldığında kendini kötü ve yalnız hissetmez. Özel öğrenci sınıfta arkadaş edinebilir ve bu arkadaşılık ona çeşitli sorunlarda yadımıcı olabilir. Arkadaşlık edindiği okulda özel öğrencinin okula gelme isteği artar ve bu onun gelişimi ve eğitimi için çok önemlidir.

Sorulan soruda: "Normal gelişim gösteren öğrenciler kaynaştırma öğrencileriyle eşyalarını, araç gereçlerini paylaşarak yardımlaşmayı öğrenmektedir” öğretmenlerin \%84.8'i evet cevabını vermişitrler ve \%15.2'si kararsız olduklanı vurgulamıştırlar. Sosyalleşmek sadece özel öğrenci için değil, her öğrenci için önemlidir. Öğrenciler sınıftaki özel arkadaşına zamanla çok fazla alışırlar ve artık onun arkadaşı gibi değil kardeşi gibi davranır. Bu davranış hem özel öğrenci için çok önemlidir hemde normal öğrencinin anlayışı, merhametli, yardımsever olmasına yardımcı olur.

Öğretmenlerimize soruduğumuz soruda: “Okullarda uygulanan kaynaştırma uygulamalarında araç gereç eksiklikleri vardır”, öğretmenlerimizin \%73.9'u buna katılmaktadır, bunun sebebi de Kosova'da, Eğitim Bakanlığın maddi durumlardan dolayı okullarda, sınıflarda araç-gereç eksiklikleri vardır.

Sorulan soruda: "Kaynaştırma uygulamasında velinin ilgisi çocuğun sosyalleşmesini etkilemektedir” örğretmenlerimizin \%84.8'i katıldıklarını onaylamışdırlar. Eğer veliler çocuğunun 
özel oduğunu zamnıyla kabullenirse onların eğitimine sosyalleşmelerine yardımıcı olurlar. Her zaman anne-baba ve öğretmen işbirliği, çocuğa yardımcı olur. Aynı zamanda özel çocukların velileri, çocukları özel olduğu için diğer öğrencilere karşı öğretmenin adaletsizlik yapmalarını beklememelidir.

Kaynaştırma Öğrencilerin Sergilediği Problem Davranışlara Yönelik Öğretmenlerin Uyguladıkları Önleme ve Müdahale Stratejileri ve Yöntemleri hakkında bilgilenmeleri amacıyla Kosova Eğitim Bilim ve Teknoloji Bakanlığı (KEBTB) tarafından hizmetiçi eğitim verilmesi önerilmektedir.

Kaynaştırma öğrencilerin davranışları hakkında okul yönetimi tarafından ailelere bilgilendirme toplantıları yapmaları önerilmektedir.

\section{KAYNAKÇA}

ŞAHBAZ, Ü., \& KALAY, G. (2010). Okulöncesi eğitimi öğretmen adaylarının kaynaştırmaya ilişkin görüşlerinin belirlenmesi. Mehmet Akif Ersoy Üniversitesi Eğitim Fakültesi Dergisi, (19), 116-135.

Gözün, Ö., \& YIKMIŞ, A. (2004). Öğretmen adaylarının kaynaştırma konusunda bilgilendirilmelerinin kaynaştırmaya yönelik tutumlarının değişimindeki etkililiğ. Ankara Üniversitesi Eğitim Bilimleri Fakültesi Özel Eğitim Dergisi, 5(02).

Kircaali-Iftar, G., Birkan, B., \& Uysal, A. (1998). Comparing the effects of structural and natural language use during direct instruction with children with mental retardation. Education and Training in Mental Retardation and Developmental Disabilities, 375-385.

Sucuoğlu, B., \& Kargın, T. (2006). İlköğretimde Kaynaştırma Uygulamaları, Morpa Kültür Yayınları.

Özdemir, S. M. (2008). Sınıf öğretmeni adaylarının öğretim sürecine ilişkin öz-yeterlik inançlarının çeşitli değişkenler açısından incelenmesi. Kuram ve Uygulamada Eğitim Yönetimi, 54(54), 277-306.

Büyüközkan, G., \& Güleryüz, S. (2014). A new GDM based AHP framework with linguistic interval fuzzy preference relations for renewable energy planning. Journal of Intelligent \& Fuzzy Systems, 27(6), 31813195.

Sarier, N., \& Onder, E. (2007). The manufacture of microencapsulated phase change materials suitable for the design of thermally enhanced fabrics. Thermochimica acta, 452(2), 149-160.

Erbaş, D., Kırcaali-Iftar, G., \& Tekin-Iftar, E. (2005). Işslevsel değerlendirme: Davranış sorunlarıyla başa çıkma ve uygun davranışlar kazandırma süreci. Kök Yayıncılık.

Esen, B., \& Gümüşçü, Ş. (2017). A small yes for presidentialism: The Turkish constitutional referendum of April 2017. South European Society and Politics, 22(3), 303-326. 
Dasen, G., Smutny, J., Teuber, M., \& Meile, L. (1998). Classification and identification of propionibacteria based on ribosomal RNA genes and PCR. Systematic and applied microbiology, 21(2), 251-259.

KAYIGIL, Ö., AHMED, S. I., \& METIN, A. (1999). The coexistence of intrinsic sphincter deficiency with type II stress incontinence. The Journal of urology, 162(4), 1365-1366.

BAĞLI, M. (1993). Görme özürlülere götürülen eğitsel hizmetler ve bu hizmetlerin geliştirilmesi. Ankara Üniversitesi Eğitim Bilimleri Fakültesi Özel Eğitim Dergisi, 1(03).

Cavkaytar, A., \& Diken, I. (2005). Introduction to special education. Kök Yayıncılık.

Bender, W. N., Vail, C. O., \& Scott, K. (1995). Teachers attitudes toward increased mainstreaming: Implementing effective instruction for students with learning disabilities. Journal of learning disabilities, 28(2), 87-94.

Sarı, A., \& Kaygusuz, K. (2003). Some fatty acids used for latent heat storage: thermal stability and corrosion of metals with respect to thermal cycling. Renewable Energy, 28(6), 939-948.

Kırcaali-iftar, G., \& Batu, S. (2007). Kaynaştırma (3. baskı). Ankara: Kök.

Gültekin Seylan, E., \& Varol Özyürek, N. (2015). Öğretmen performansı dikkate alınarak doğrudan öğretim yaklaşımıyla sunulan hizmet içi eğitim programının etkililiği.

DAĞLI GÖKBULUT, Ö., AKÇAMETE, G., \& GÜNEYLİ, A. (2020). BİRLİKTE ÖĞRETIM UYGULAMALARININ ÖZEL GEREKSINIMLI ILKOKUL ÖĞRENCILERININ OKUDUĞUNU ANLAMA BECERILERINE ETKISI. Electronic Journal of Social Sciences, 19(74).

DEMiR, M. K., \& Seçil, A. Ç. A. R. (2010). Sınıf öğretmenlerinin kaynaştırma eğitimine ilişkin düşünceleri. Gazi Üniversitesi Gazi Eğitim Fakültesi Dergisi, 30(3), 749-770.

Aydemir, H., Diken, İ. H., Yıkmış, A., Aksoy, V., \& Özokçu, O. (2015). Özel Eğitim Alaninda Çalişan Öğretmenlerin Tükenmişlik Düzeyleri ve Yaşam Doyumlarinin İncelenmesi. Abant İzzet Baysal Üniversitesi Eğitim Fakültesi Dergisi.

Battal, İ. (2007). Sınıf öğretmenlerinin ve branş öğretmenlerinin kaynaştırma eğitimine ilişkin yeterliliklerinin değerlendirilmesi (Uşak ili örneği) (Master's thesis, Afyon Kocatepe Üniversitesi, Sosyal Bilimler Enstitüsü). 